\author{
UNIVERSITY OF CALIFORNIA \\ COLLEGE OF AGRICULTURE \\ AGRICULTURAL EXPERIMENT STATION \\ BERKELEY, CALIFORNIA
}

\title{
The Emergence of Pear Thrips in the Healdsburg Area of California in 1932
}

LESLIE $M$. SMITH

BULLETIN 562

NOVEMBER, 1933 


\section{ACKNOWLEDGMENTS}

Credit for the successful operation of the thrips traps is largely due to H. A. Weinland, Farm Advisor, Sonoma County, and numerous growers who coöperated with the University in this test. G. E. Stanley, manual training teacher in the Healdsburg High School, and his students constructed the traps. 


\title{
THE EMERGENCE OF PEAR THRIPS IN THE HEALDSBURG AREA OF CALIFORNIA IN $1932^{1}$
}

\author{
LESLIE M. SMITH ${ }^{2}$
}

Unsatisfactory control of pear thrips, Taeniothrips inconsequens (Uzel), has frequently been reported within the last few years by the prune growers in the Healdsburg district of Sonoma County, California. Many growers were of the opinion that the thrips emerged from the soil for a much longer period in this area than is usually the case in other areas. It was suggested that the emergence from the soil in the Santa Clara Valley, where sprays and dusts have proved effective, might be much shorter, so that one or two applications yielded an effective control. In order to gather definite information on the emergence of thrips in the Healdsburg area, forty-five traps were distributed through the district, and the data given in the following pages were gathered.

\section{METHOD}

Each trap was shaped like a four-sided pyramid (figs. 1 and 2), with the base 3 feet square and the apex 2 feet in height. The base was constructed of $1 \times 2$ inch redwood. From each corner of the base a piece of $1 \times 1$ inch redwood extended at an angle of about $45^{\circ}$ to a small block $3 / 4 \times 3 \times 3$ inches at the top. In the center of the top of the block a hole was bored half way through of such size as to admit a small vial. This hole was continued by a smaller hole which opened on the lower side of the block (fig. $1 C$ ). A vial could be inserted in the hole in the top of the block. and the rim of the smaller hole formed a shoulder on which the mouth of the inverted vial rested when installed.

The frame was covered with a cheap but close-mesh muslin. The cloth was applied to the inside of the frame in order to reduce recesses which would impede the progress of the thrips or serve as hiding places for them. The cloth was tacked to the frame, the edges were then covered with half-round screen molding, and three coats of Tree-White were applied to the inside (fig. $1 B$ ). White was selected as the most desirable

1 Received for publication October 11, 1932.

2 Junior Entomologist in the Experiment Station. 

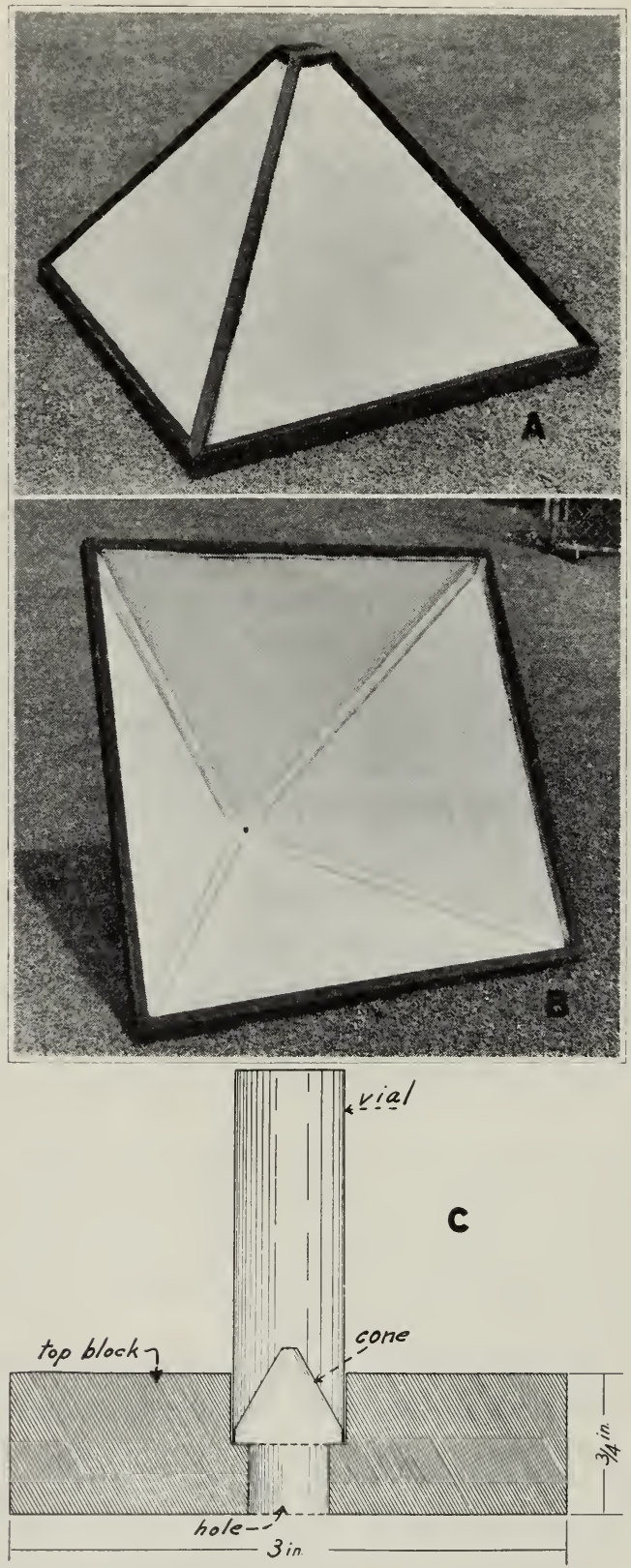

Fig. 1.-A, Exterior of trap. The hole in the top is for the insertion of the vial. $B$, Interior of trap. $C$, Section of vial, cone, and block at the top of the pyramid, showing arrangement and method of insertion. 
color, since it would contrast with any adult, or "black" thrips which failed to pass from the pyramid into the vial, and by inverting the trap and counting the thrips on the inside the efficiency of the trap could be determined.

Although three successive coats of paint were applied to the inside of the traps, there still remained minute openings through the cloth, which in some cases were large enough to permit a thrips to pass through. As a check on the efficiency of the cloth traps, a number of traps were covered on the outside with a medium-weight roofing paper which was strapped along the edges by screen molding.

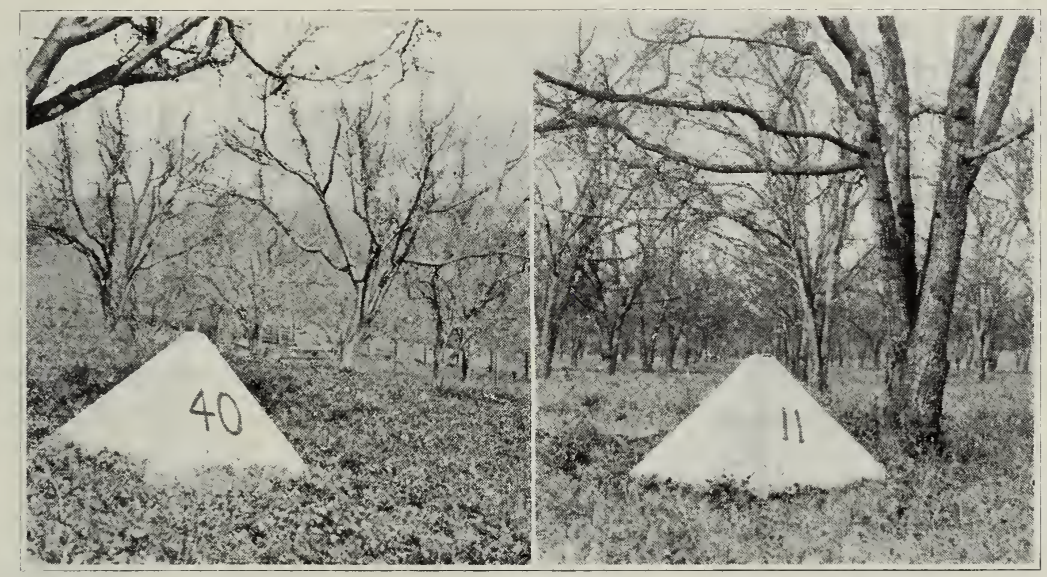

Fig. 2.-Traps in position in the field. Left, cloth; right, paper-covered trap.

The vials inserted in the tops of the cones were prepared to function as traps, similar to the common fly trap. A small truncate cone was glued in the mouth of each vial. In order not to impede the passage of light, necessary to attract the thrips to the top of the trap, the cone inside of the vial was constructed of transparent paper (Cellophane) and held in place by water-proof cement.

The traps were placed in the hands of the growers, with mimeographed directions describing the procedure to be followed and with materials to enable them to carry out the instructions. Growers were requested (1) to remove the vial from the top of the trap every second day, at the same hour, preferably in the morning, and replace with an empty vial; (2) to place a cotton plug in the end of the vial and pour on it a few drops of ether to kill the thrips; (3) to mark the vial with the trap number and date removed; (4) to move the trap to a new location in the same ricinity at the time of changing the vial, that is, every second day. 
If the trap had stood on bare soil (that is, on soil from which the covercrop had been cut immediately before the trap was placed) they were requested to cut off the covercrop before placing the trap, otherwise to place it over the covercrop. The traps were moved every second day in order to avoid any change in soil temperature which might have resulted had the trap stood for a long period on the same square yard. Each time after the traps were moved, the lower edges of the frames were covered with soil to exclude light. At regular intervals the vials were collected, and the thrips removed and counted. The traps were distributed in the Healdsburg area in such a way as to cover as wide a variety of cultural practices as possible. An attempt was made to gather information on the relation of soil types, irrigation, and covercrops to thrips emergence.

In order to facilitate a comparison of results, each catch was divided equally between the days during which the vial was on the trap. With very few exceptions, the coöperators followed directions and changed the vials every second day. Traps were placed in representative orchards which were known to have been infested with thrips the preceding spring. Each trap was placed near the base of a tree, under as much of the top as possible (fig. 2), since it was presumed that the majority of thrips drop straight to the ground and transform and emerge without much lateral movement.

\section{RESULTS}

Efficiency of the Traps.-During the first few days of the emergence several questions bearing on the efficiency of the traps were settled. A comparison was made between the catches in cloth-covered traps and those in cages which, in addition to cloth, were covered with roofing

TABLE 1

EFFiciency of TyPes of Traps

\begin{tabular}{l|c|c|c|c}
\hline \multirow{2}{*}{ Type of trap } & \multicolumn{3}{|c}{ Total thrips caught } \\
\cline { 2 - 5 } & First set & Second set & Third set & Average \\
\hline Roofing paper & 37 & 1,373 & 1,623 & 1,011 \\
Cloth & 190 & 571 & 2,165 & 975 \\
\hline
\end{tabular}

paper. In several cases these two types of traps were placed within a few feet of each other and kept in this relation throughout the period of this test. The total catches of three such pairs of traps were as indicated in table 1. 
From these counts it may be seen that the traps covered with roofing paper in addition to cloth were no more efficient than traps which were covered with cloth alone. The counts from these traps are included among those given in table 2. During the course of the experiment several factors appeared which indicated the superiority of the cloth alone. It was found that the temperature and humidity rose much higher in the paper-covered traps. Water condensed on the cloth and in the vial and interfered with the counting of the thrips. The paper-covered cages were more expensive to construct, heavier to handle, and more apt to break or puncture.

On numerous occasions when the vial at the top of the trap was found to contain a considerable catch, the trap was inverted and examined on the inside for thrips. Thrips were rarely found on the sides of the trap, and at most in very small numbers. From such observations it was concluded that after leaving the soil, or the covercrop, the thrips moved rapidly up the sides of the pyramid and entered the vial at the top.

Occasionally spiders caught in the traps constructed webs over the mouths of the vials and preyed upon the thrips and thus reduced the efficiency of the traps. Such spiders were removed as frequently as found. They rarely interfered with the operation of the trap for more than two days.

Total Emergence.-Twenty-one traps were placed in the field on February 18. On February 21, eleven of these had caught some thrips. The total accumulated catch on this day was 44 . When this catch is divided as equally as possible between the three days during which the thrips were caught, and the odd thrips included with the catch on the latest day, the average catch per trap was as follows :

Date, 1932

February 19

February 20

February 21
Daily emergence, thrips per sq. yard
Cumulative total, thrips per sq. yard

$\begin{array}{ll}0.5 & 0.5 \\ 0.7 & 1.2 \\ 1.0 & 2.2\end{array}$

While a few thrips may have emerged prior to February 19, the number must be very small and for the purposes of this paper, may be disregarded. The emergence on February 18 and preceding days is regarded as zero in the following computations.

The total number of thrips caught in the Healdsburg section (table 2) has been utilized in preparing the graphs of total emergence, figure $3 \mathrm{~A}$ and $B$. 
These data include emergences from irrigated and nonirrigated soils, light, medium, and heavy soil types, and various covererop conditions. They may therefore be regarded as covering nearly all possible times of emergence, and present an approximation of the average emergence of all conditions. No records of soil temperatures were kept. The mean daily

\section{TABLE 2}

Total Emergence in the Healdsburg Area

\begin{tabular}{|c|c|c|c|c|c|c|c|c|c|}
\hline \multirow[b]{2}{*}{ Date, 1932} & \multirow[b]{2}{*}{$\begin{array}{l}\text { Total } \\
\text { thrips }\end{array}$} & \multirow{2}{*}{$\begin{array}{l}\text { Num- } \\
\text { ber of } \\
\text { traps }\end{array}$} & \multicolumn{2}{|c|}{$\begin{array}{l}\text { A verage thrips } \\
\text { per square yard* }\end{array}$} & \multirow[b]{2}{*}{ Date, 1932} & \multirow[b]{2}{*}{$\begin{array}{l}\text { Total } \\
\text { thrips }\end{array}$} & \multirow{2}{*}{$\begin{array}{l}\text { Num- } \\
\text { ber of } \\
\text { traps }\end{array}$} & \multicolumn{2}{|c|}{$\begin{array}{l}\text { A verage thrips } \\
\text { per square yard* }\end{array}$} \\
\hline & & & Daily & $\begin{array}{l}\text { Cumu- } \\
\text { lative } \\
\text { total }\end{array}$ & & & & Daily & $\begin{array}{l}\text { Cumu- } \\
\text { lative } \\
\text { total }\end{array}$ \\
\hline 1 & 2 & 3 & 4 & 5 & 1 & 2 & 3 & 4 & 5 \\
\hline Feb. 19 & 10 & 21 & 0.3 & 0.3 & Mar. 9 & 2,208 & 43 & 33.4 & 247.9 \\
\hline Feb. 20 & 15 & 21 & 0.5 & 0.8 & Mar. 10 . & 1,487 & 43 & 22.5 & 270.4 \\
\hline Feb. 21 & 20 & 21 & 0.7 & 1.5 & Mar. 11 & 1,148 & 43 & 17.6 & 288.0 \\
\hline Feb. 22 & 22 & 21 & 0.7 & 2.2 & Mar. 12 & 1,103 & 43 & 16.7 & 304.7 \\
\hline Feb. 23 & 128 & 21 & 4.0 & 6.2 & Mar. 13. & 975 & 43 & 14.8 & 319.5 \\
\hline Feb. 24 & 249 & 35 & 4.6 & 10.8 & Mar. 14 & 765 & 43 & 11.6 & 331.1 \\
\hline Feb. 25 & 487 & 39 & 8.1 & 18. 9 & Mar. 15. & 791 & 41 & 12.6 & 343.7 \\
\hline Feb. 26 & 501 & 41 & 7.9 & 26.8 & Mar. 16 & 614 & 41 & 9.8 & 353.5 \\
\hline Feb. 27 & 586 & 42 & 9.1 & 35.9 & Mar. 17 & 335 & 39 & 5.6 & 359.1 \\
\hline Feb. 28 & 1,079 & 41 & 17.1 & 53.0 & Mar. 18 & 231 & 38 & 4.0 & 363.1 \\
\hline Feb. 29 & 1,318 & 41 & 20.9 & 73.9 & Mar. 19 & 210 & 38 & 3.6 & 366.7 \\
\hline Mar. 1 & 902 & 40 & 14.7 & 88.6 & Mar. 20 & 149 & 36 & 2.7 & 369.4 \\
\hline Mar. 2 & 1,293 & 40 & 21.0 & 109.6 & Mar. 21 & 175 & 35 & 3.3 & 372.7 \\
\hline Mar. 3 & 1,505 & 39 & 18.6 & 128.2 & Mar. 22 & 76 & 26 & 1.9 & 374.6 \\
\hline Mar. 4 & 952 & 38 & 16.3 & 144.5 & Mar. 23 & 39 & 26 & 1.0 & 375.6 \\
\hline Mar. 5 & 637 & 42 & 9.9 & 154.4 & Mar. 24 & 43 & 24 & 0.9 & 376.5 \\
\hline Mar. 6. & 915 & 41 & 14.5 & 168.9 & Mar. 25 & 26 & 20 & 0.8 & 377.3 \\
\hline Mar. 7 & 1,018 & 41 & 16.1 & 185.0 & Mar. 26 & 14 & 18 & 0.4 & 377.7 \\
\hline Mar. $8 \ldots$ & 1,949 & 43 & 29.5 & 214.5 & Mar. 27. & 3 & 18 & 0.1 & 377.8 \\
\hline
\end{tabular}

* Since some of the traps were on bare soil and some on the covercrop, the counts given in these two columns have been corrected by the formula:

$$
\frac{\frac{10 T}{N}+33\left(\frac{10.84 T}{19.82 N}\right)}{43}
$$

in which 10 is the number of traps on bare soil. 33 is the number of traps on covercrop (see covercrop data, table 3), 43 is the total number of traps, $T$ is the total thrips caught on any day (given in col. 2 of table 2), $N$ is the number of traps on the same day (given in col. 3 of table 2), 10.84 is the average thrips per square yard emerging throughout the season from clean soil, and 19.82 is the number of thrips per square yard emerging throughout the season from soil under a covercrop. This formula is used to subtract those thrips which were on the covercrop at the time the traps were placed over it.

temperatures recorded at Santa Rosa are indicated by the dashed line in figure $3 \mathrm{~A}$. The arithmetical mean of the curve of emergence falls on the twentieth day of the test, or on March 9. The curve shown in figure $3 \mathrm{~A}$ approximates the form of the normal curve except between the first and seventh of March. At this time a sharp depression in the numbers of thrips occurred. A study of the graph (fig. $3 A$ ) will show that this depression is correlated with a sharp depression of the mean tempera- 
ture. During the first three days of lower temperatures the number of thrips emerging increased slowly; during the second three days of cold weather, the number emerging showed a marked decrease. It may be that the soil retained sufficient heat from the warm period of February 27-29 to account for the slight increase in emergence of thrips on March 2. The drop in mean temperature is therefore probably responsible for the departure in emergence from the expectancy indicated by the cumulative curve in figure $3 B$.
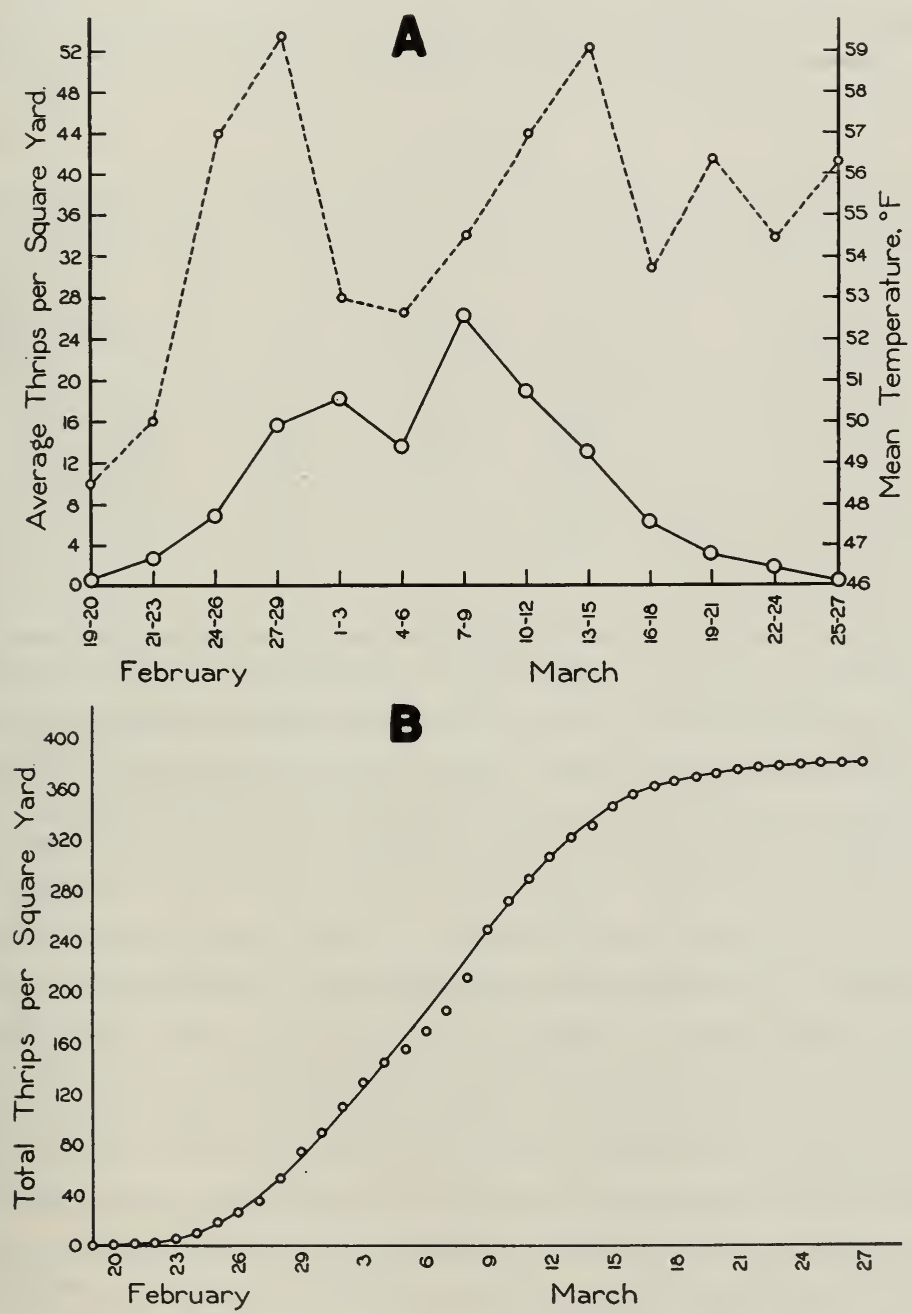

Fig. 3.-Emergence in the Healdsburg area in relation to temperature. The continuous line shows the emergence; the dashed line slows the mean temperature, based on three-day averages. (Data from table 2.) $B$, Accumulated total of average thrips per square yard. (Data from table 2.) 
The total number of thrips emerging during the entire season averaged 377.8 per trap. This means that in orchards that were infested in the spring of 1931 every square yard that was overhung by branches gave egress to 378 thrips, on the average, this spring. The total period of emergence extended from February 19 until March 27, or a total of 38 days. The average daily emergence throughout the entire period from February 19 to March 27 was 9.9 thrips per square yard. The largest catch was 1,234 thrips in two days, or 617 thrips per square yard per day. Significant emergence, arbitrarily selected at 5 or more thrips per square yard, extended from February 23 to March 21, or a total of 28 days.

\section{TABLE 3}

Comparison of Significant Emergence Periods, Healdsburg and San Jose

\begin{tabular}{|c|c|c|c|c|c|}
\hline Locality & Year & $\begin{array}{c}\text { First } \\
\text { emergence }\end{array}$ & Mode & $\begin{array}{c}\text { Last } \\
\text { emergence }\end{array}$ & $\begin{array}{l}\text { Length of } \\
\text { emergence } \\
\text { period, } \\
\text { days }\end{array}$ \\
\hline San Jose. & 1909 & Feb. 15 & Mar. 3 & Mar. 20 & 33 \\
\hline San Jose & 1910 & Feb. 9 & Mar. 4 & Mar. 17 & 36 \\
\hline San Jose.. & 1911 & Feb. 7 & Mar. 12 & Mar. 18 & 39 \\
\hline San Jose.... & 1912 & Feb. 6 & Mar. 1 & April 8 & 62 \\
\hline Healdsburg. & 1932 & Feb. 23 & Mar. 9 & Mar. 21 & 28 \\
\hline
\end{tabular}

The traps were moved every second day, as stated above, to a new location. In order to gather information regarding the total number of thrips in a selected square yard, and to obtain data for comparison with traps which were moved, three traps were left stationary throughout the emergence period on the spot where they were first placed. These traps caught a total of $311,1,853$, and 1,211, or an average of 10.0,66.2, and 60.6 thrips per day, respectively. These three traps computed together show an average of 42.6 thrips per square yard per day, which is considerably in excess of the average emergence of all the traps, 9.9.

A comparison of the length of the emergence period in the Healdsburg area with that in the San Jose area is possible by contrasting the data herein presented with that obtained by Foster and Jones $^{3}$ in San Jose. In table 3 "first emergence" and "last emergence" refer to "significant emergence" as described above. The dates for San Jose, 1909-1912, are taken from Foster and Jones. Although the data from the two studies were obtained by somewhat different techniques, they are sufficiently comparable to indicate that the emergence period in the Healdsburg

3 Foster, S. W., and P. R. Jones. The life history and habits of the pear thrips in California. U. S. Dept. Agr. Bul. 173:33, table IV. 1915. 
area is not appreciably longer than in the San Jose area. Foster and Jones reared thrips from blocks of soil removed intact from infested orchards, and carried to their laboratory. In this paper, their data has been computed to thrips emerging per square yard of surface soil, and again significant emergence is recognized as 5 or more thrips emerging per square yard per day.

Covercrop.-Covercrops are generally believed to retard thrips emergence. This may be due to the fact that the covercrop shades the soil and maintains a lower temperature therein. No study of such a hypothesis was conducted during the test, but the relation of the total emergence to the mean temperature, already discussed, lends some support to it.

A second method by which the covercrop may delay the appearance of the thrips consists in retarding the flight of the emerged adults to the trees. In other words the covercrop may serve as a temporary abode for the adults. In order to obtain information on this question, ten of the forty-three traps reported upon in table 2 were placed on bare soil, that is, on undisturbed soil from which the covercrop was cut, just prior to placing the traps. These traps were moved every second day, and each time the covercrop was cut and removed before they were placed. In table 4 the daily average per trap computed from ten traps on clean soil is contrasted with the daily average per trap of thirty-three traps which were moved every second day and placed over fresh covercrop. As will be shown later, the emergence per square yard is greatly modified by soil types. Although the traps used in this covercrop test were placed on all types of soils, the soil factor does not render the results incomparable since of the bare-soil traps 70.0 per cent were placed on medium and heavy soils and of the covercrop traps 78.8 per cent were placed on soils of this type.

It was assumed that the average number of thrips emerging from freshly cleaned soil would approximate the number of thrips emerging from soil under a covercrop. Any additional thrips caught in traps on the covercrop were presumed to have emerged earlier and to have been resting on the covercrop when the trap was placed over it. The number thus present on the covercrop (column 4 in table 4) is computed as the difference between catches from the covercrop and from bare soil. The thrips on the covercrop probably enter the vial during the first twentyfour hours after the trap is placed because of their pronounced positive phototropism. During the second twenty-four hours the catch in covercrop traps is increased only by the further emergence from the soil. Since the traps were moved only once in two days, these two values are 
averaged. If the traps had been moved every day, the number of thrips caught in the covercrop traps would probably have been nearly doubled.

These data show that the number of thrips per square yard remaining on the covercrop, after emerging, increased from none on February 19

TABLE 4

Number of Thrips Remaining on Covercrop

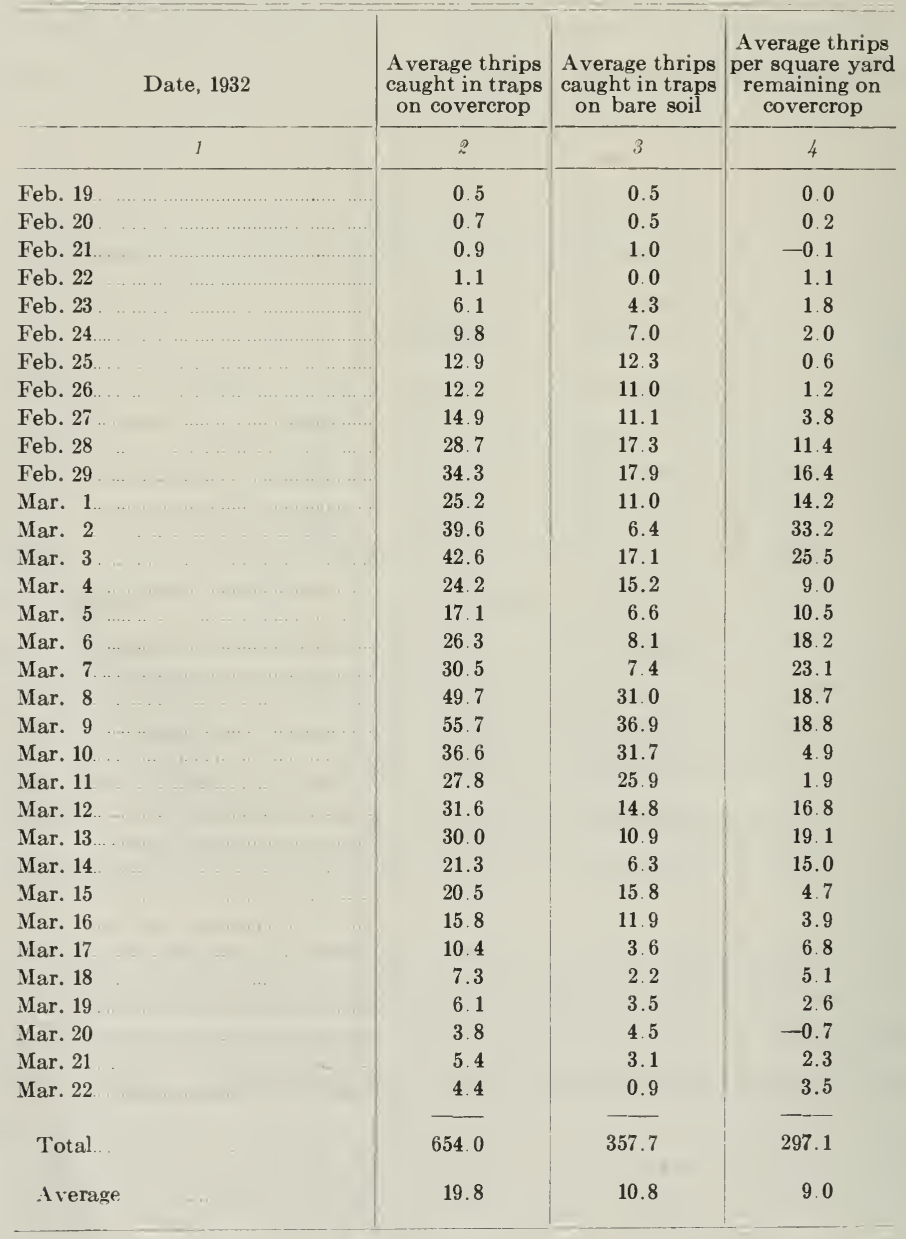

to 33.2 on March 2. From March 2 on, the number of thrips remaining on the covercrop decreased. From this standpoint alone, it would seem that the covercrop acted as an important retarding factor up to March 2, at which time its importance in this connection began to decrease, so 
that the orchards could have been disked any time after March 2 without appreciably affecting the numbers of thrips on the trees.

Irrigation.-Fall irrigation has been both recommended and condemned in the literature as a means of destroying pear thrips in the soil.

TABLE $\tilde{0}$

EFFeCt of Irrigation on THRIPS EMIERgence

\begin{tabular}{|c|c|c|c|c|}
\hline \multirow{2}{*}{ Date, 1932} & 3 irrigations & 2 irrigations & 1 irrigation & No irrigations \\
\hline & \multicolumn{4}{|c|}{ Average thrips per square yard } \\
\hline Feb. $19 \ldots$ & 2.0 & 0.5 & 0.0 & 0.0 \\
\hline Feb. $20 \ldots$ & 3.0 & 0.5 & 0.0 & 1.0 \\
\hline Feb. 21.... & 3.0 & 1.0 & 0.0 & 1.0 \\
\hline Feb. $22 \ldots$ & 1.0 & 0.5 & 0.0 & 0.0 \\
\hline Feb. $23 \ldots$ & 2.0 & 34.0 & 1.0 & 1.0 \\
\hline Feb. $24 \ldots$ & 22.3 & 27.7 & 2.0 & 0.7 \\
\hline Feb. 25...... & 25.0 & 83.0 & 1.8 & 1.3 \\
\hline Feb. $26 \ldots$ & 25.3 & 83.0 & 1.8 & 1.3 \\
\hline Feb. $27 \ldots$ & 25.3 & 83.7 & 1.8 & 1.3 \\
\hline Feb. $28 \ldots$ & 16.7 & 136.0 & 0.3 & 1.7 \\
\hline Feb. $29 \ldots$ & 16.7 & 136.3 & 0.7 & 1.7 \\
\hline Mar. $1 \ldots$ & 0.0 & 2.0 & 0.0 & 49.7 \\
\hline Mar. $2 \ldots$ & 0.0 & 2.5 & 0.0 & 49.7 \\
\hline Mar. $3 \ldots$ & 14.7 & 31.5 & 3.0 & 14.0 \\
\hline Mar. $4 \ldots$ & 14.7 & 32.0 & 4.0 & 14.3 \\
\hline Mar. $5 \ldots \ldots$ & 1.0 & 4.3 & 4.5 & 17.0 \\
\hline Mar. $6 \ldots \ldots$ & 1.3 & 4.3 & 4.8 & 17.3 \\
\hline Mar. $7 \ldots \ldots$ & 2.0 & 5.0 & 5.3 & 17.7 \\
\hline Mar. $8 \ldots$ & 0.3 & 5.0 & 6.8 & 24.7 \\
\hline Mar. $9 \ldots$ & 0.3 & 5.0 & 7.3 & 25.0 \\
\hline Mar. $10 \ldots \ldots \ldots$ & 3.3 & 7.3 & 10.0 & 42.3 \\
\hline 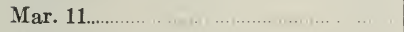 & 4.0 & 7.7 & 10.3 & 43.3 \\
\hline Mar. $12 \ldots \ldots$ & 1.7 & 1.3 & 63.0 & 20.7 \\
\hline Mar. 13....... & 1.7 & 2.0 & 63.5 & 21.3 \\
\hline Mar. 14.......... & 0.3 & 0.0 & 33.5 & 6.7 \\
\hline Mar. 15 & 5.0 & 0.0 & 33.8 & 7.0 \\
\hline Mar. $16 \ldots$ & 1.0 & 0.7 & 34.3 & 7.3 \\
\hline .... …n & 0.0 & 0.3 & 11.5 & 0.3 \\
\hline Mar. $18 \ldots \ldots$ & 0.3 & 0.7 & 11.5 & 0.7 \\
\hline Mar. $19 \ldots \ldots \ldots$ & 1.0 & 0.0 & 12.0 & 1.0 \\
\hline Mar. 20... & 0.3 & 2.0 & 5.3 & 0.0 \\
\hline 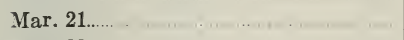 & 0.7 & 2.0 & 5.3 & 0.0 \\
\hline Mar. $22 \ldots \ldots$ & 0.7 & 2.0 & 6.3 & 0.3 \\
\hline 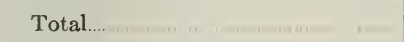 & 196.6 & 703.8 & 345.4 & 391.3 \\
\hline Average. & 6.0 & 21.3 & 10.5 & 11.9 \\
\hline
\end{tabular}

With the coöperation of Blaine McClish the following test of the efficiency of irrigation was conducted. Portions of his orchard were irrigated once, twice, and three times, while a fourth portion was not irrigated. The contour-check system of irrigation was used. At each irrigation, the land received approximately 6 acre-inches of water. The 
three irrigations were applied on July 21, August 28, and September 29; the two irrigations were applied on August 28 and September 29; and the single irrigation was applied on September 29. Three emergence traps were placed in each irrigated area and three in the nonirrigated portion. The counts from these traps were included among those given

TABLE 6

EMERgence of Thrips From Heavy ANd Light SoILS

\begin{tabular}{|c|c|c|c|c|}
\hline & Date, 1932 & $\begin{array}{c}\text { Heavy and } \\
\text { medium soils, } \\
\text { average thrips } \\
\text { per square yard }\end{array}$ & $\begin{array}{c}\text { Light soils, } \\
\text { average thrips } \\
\text { per square yard }\end{array}$ & $\begin{array}{c}\text { Increase in } \\
\text { average thrips } \\
\text { per square yard } \\
\text { surviving in } \\
\text { heavy soils }\end{array}$ \\
\hline Feb. 19 & & 0.6 & 0.0 & 0.6 \\
\hline Feb. 20 &. & 0.9 & 0.0 & 0.9 \\
\hline Feb. $21 \ldots$ & & 1.1 & 0.0 & 1.1 \\
\hline Feb. 22 & ... & 1.3 & 0.0 & 1.3 \\
\hline Feb. 23 & & 7.8 & 0.0 & 7.8 \\
\hline Feb. 24 & & 11.3 & 1.4 & 9.9 \\
\hline Feb. 25 & $x$ & 16.6 & 0.4 & 16.2 \\
\hline Feb. 26 & & 14.6 & 0.8 & 13.8 \\
\hline Feb. 27 & - & 18.9 & 1.6 & 17.3 \\
\hline Feb. 28 & 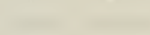 & 34.7 & 1.8 & 32.9 \\
\hline Feb. 29 & $=$ & 41.1 & 2.2 & 38.9 \\
\hline Mar. 1 & & 28.6 & 2.7 & 25.9 \\
\hline Mar. 2 & & 41.7 & 3.7 & 38.0 \\
\hline Mar. 3. & 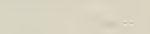 & 47.9 & 5.0 & 42.9 \\
\hline Mar. 4 & & 28.4 & 4.2 & 24.2 \\
\hline Mar. 5. & 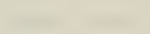 & 18.0 & 3.8 & 14.2 \\
\hline Mar. 6. & & 27.8 & 3.8 & 24.0 \\
\hline Mar. $7 \ldots$ & & 31.7 & 4.3 & 27.4 \\
\hline Mar. 8 & 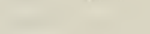 & 58.8 & 4. 1 & 54.7 \\
\hline Mar. 9. & $a^{2}$ & 67.1 & 3.3 & 63.8 \\
\hline Mar. 10. & . & 25.8 & 40 & 21.8 \\
\hline Mar. 11. & 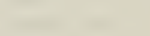 & 33.8 & 7.3 & 26.5 \\
\hline Mar. 12 & $=$ & 34.6 & 7.0 & 27.6 \\
\hline Mar. 13 & & 32.1 & 5.4 & 26.7 \\
\hline Mar. 14 & 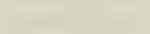 & 20.8 & 10.4 & 10.4 \\
\hline Mar. 15 & $-2=$ & 21.6 & 11.8 & 9.8 \\
\hline Mar. 16 & - & 16.3 & 10.2 & 6.1 \\
\hline Mar. 17 & & 9.6 & 7.0 & 2.6 \\
\hline Mar. 18 & 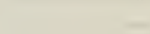 & 6.4 & 5.5 & 0.9 \\
\hline Mar. 19 & & 5.4 & 5.9 & -0.5 \\
\hline Mar. 20 & 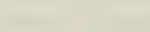 & 5.1 & 1.3 & 3.8 \\
\hline Mar. 21 & & 5.8 & 1.5 & 4.3 \\
\hline Mar. 22 & & 3.2 & 0.7 & 25 \\
\hline Total & & 7194 & 121.1 & 599.3 \\
\hline Average & & 21.8 & 3.7 & 18.2 \\
\hline
\end{tabular}

in table 2 . The data in table 5 were gathered. These data are so irregular that it is difficult to base an opinion on them. They indicate, however, that under some conditions as many as two irrigations applied late in August and September fail to reduce materially the number of thrips which emerge the following spring. 
Several orchards were flooded in December, 1931, when, as a result of heavy rains, the Russian River overflowed its banks. Three traps were placed on situations that had been submerged from $1 \frac{1}{2}$ to 6 feet deep, and for periods of one to several days. The data from these traps are included in table 2 . These traps caught a total of $277,1,334$, and 1,894 thrips, or an average of 40.3 thrips per square yard per day. This is considerably greater than the average daily emergence, 9.9.

The data gathered on emergence from irrigated and flooded land indicate that under certain conditions even large amounts of water are not inimical to thrips survival.

Soil Types.-The soils involved in this test were classified before the emergence into three groups: heavy, medium, and light. The data in table 6 are based on ten traps on light soils and thirty traps on heavy and medium soils. The data from these traps are included in table 2. These two latter types are treated as one, since no appreciable differences existed in numbers of thrips emerging from them. All of the traps were placed in orchards where thrips were known to have been injurious the preceding spring, so that the numbers of thrips which entered the various soil types were probably similar.

These data show a much greater emergence of thrips from heavy than from light soils. The emergence from heavy soils was more than twenty times as great as that from light soils on March 9 and averaged about six times as great throughout the period of emergence.

Control Measures to Reduce the Thrips Population the Following Spring.-Considerable importance is attached to the possibility of killing the larvae while still on the trees, in order to reduce the thrips population the following spring. During the spring of 1931 various growers applied sprays and dusts in an attempt to control adults and larvae. Many of the traps used in these emergence tests were placed in orchards which had been sprayed and dusted the preceding spring. The types of applications and emergence of thrips from them are given in table 7.

These data fail to show any correlation between spray practice and numbers of thrips emerging the following spring. However, it should be borne in mind that the amount of spraying which is done is generally in proportion to the amount of injury or numbers of thrips present, so that the orchards which received multiple applications may be regarded as having the heaviest infestations. The counts indicate that as many as three to six applications of sprays and dusts failed to reduce the thrips population to a negligible number. 
TABLE 7

Results of Sprays and Dusts Applied the Preceding Year

\begin{tabular}{|c|c|c|c|}
\hline \multicolumn{2}{|c|}{ Control measures } & \multirow{2}{*}{$\begin{array}{c}\text { Number } \\
\text { of } \\
\text { traps }\end{array}$} & \multirow{2}{*}{$\begin{array}{l}\text { A verage daily } \\
\text { emergence } \\
\text { per square yard }\end{array}$} \\
\hline Material & $\begin{array}{c}\text { Number of } \\
\text { applications }\end{array}$ & & \\
\hline Nicotine dust.... & 1 & 1 & 60.6 \\
\hline Nicotine dust................ & 1 & 1 & 1.5 \\
\hline Nicotine dust... & 1 & 1 & 11.1 \\
\hline Nicotine spray & 1 & 1 & 15.8 \\
\hline Soap and nicotine. & 1 & 1 & 4.1 \\
\hline Nicotine dust... & 2 & 1 & 44.5 \\
\hline Nicotine dust.. & 2 & 1 & 1.2 \\
\hline Nicotine dust.. & 2 & 2 & 5.5 \\
\hline Nicotine spray $\ldots$ & 1 & & 11.1 \\
\hline Nicotine dust.... & 1 & 1 & 11.1 \\
\hline Nicotine spray & 1 & 1 & 66.2 \\
\hline Nicotine dust.. & 1 & & \\
\hline Nicotine spray & 1 & 1 & 9.0 \\
\hline $\begin{array}{l}\text { Nicotine dust... } \\
\text { Nicotine spray }\end{array}$ & $\begin{array}{l}2 \\
1\end{array}$ & & \\
\hline Nicorine dust.. & $2\}$ & 2 & 3.7 \\
\hline Nicotine dust & 6 & 3 & 432 \\
\hline None & $\ldots$ & 1 & 0.0 \\
\hline None $\ldots \ldots \ldots \ldots$ & $\ldots$ & 1 & 1.0 \\
\hline None ... ...... & $\ldots$ & 1 & 27.7 \\
\hline None $\ldots$ & $\ldots$ & 3 & 3.5 \\
\hline None... & $\ldots$ & 13 & 8.1 \\
\hline
\end{tabular}

\section{SUMMARY}

A satisfactory type of trap suitable for gauging thrips emergence was devised.

The total emergence occurred over a period of 38 days, from February 19 until March 27. The peak of the emergence (empirical mode) and the arithmetical mean occurred on March 9. The normal curve of emergence was distorted by the influence of temperature.

A covercrop was found to delay the movement of thrips to the trees, after they had emerged from the soil. The number of thrips remaining on the covercrop reached a maximum of 33.2 thrips per square yard on March 2.

Irrigation and natural flooding did not appreciably reduce the emergence.

Heavy soils showed a much greater emergence than light soils. The average daily emergence per square yard from heavy soils was 21.8 , from light soils 3.7 .

Control measures applied in the spring of 1931 did not produce demonstrable results in 1932. 